\title{
Organometallic and Classical Coordination Sites in Highly Preorganized Pyrazolate-Based Hybrid Systems: The Mn/Ni Case
}

\author{
Huaxin Zhang, ${ }^{[a]}$ Sebastian Dechert, ${ }^{[a]}$ Michael Linseis, ${ }^{[b]}$ Rainer F. Winter, ${ }^{[b]}$ and \\ Franc Meyer*[a]
}

\begin{abstract}
A series of unsymmetric heterodinuclear $\mathrm{Mn} / \mathrm{Ni}$ complexes is reported in which an organometallic $\mathrm{CpMn}(\mathrm{CO})_{2}$ fragment and a classical Werner-type nickel(II) subunit are arranged in close proximity by means of a bridging pyrazolate. The two metalloligand scaffolds ( 1 and 2 ) employed differ in the chelate size of the tripodal tetradentate $\left\{\mathrm{N}_{4}\right\}$ binding site for nickel. Molecular structures have been determined for $\left(\mathbf{1}_{-\mathrm{H}}\right)$ $\mathrm{Ni}\left(\mathrm{NO}_{3}\right)(3),\left(2_{-\mathrm{H}}\right) \mathrm{Ni}\left(\mathrm{NO}_{3}\right)(4)$, and $\left(2_{-\mathrm{H}}\right) \mathrm{Ni}(\mathrm{OAC})(5)$. Comparison with the molecular structures of the related $\mathrm{Mn} / \mathrm{Mn}, \mathrm{Mn} /$ $\mathrm{Co}$, and $\mathrm{Mn} / \mathrm{Zn}$ systems confirms that structural flexibility is greater for the complexes based on ligand 2 due to the longer chelate arms. According to IR and UV/Vis spectroelectro-
\end{abstract}

\section{Introduction}

The pyrazolate heterocycle is a well established and useful bridging unit in bimetallic complexes. ${ }^{[1]}$ Further preorganization of the two metal ions as well as modulation of their structural and electronic properties can be achieved by attaching chelating side arms to the 3- and 5-positions of the heterocycle. ${ }^{[2,3]}$ The majority of such pyrazolate-derived dinucleating ligand scaffolds are symmetric, which means that these scaffolds provide two identical coordination pockets and favor the formation of homobimetallic complexes. Unsymmetrical pyrazolate ligands that allow the targeted assembly of heterobimetallic complexes, despite the intriguing metal ion cooperativity that can be expected for those systems, ${ }^{[4]}$ are relatively scarce due to their more laborious synthesis. ${ }^{[5]}$ An interesting situation with respect to the mutual effects of the proximate metal ions arises when the distinction between the two binding sites becomes very pronounced, such as in hybrid systems that contain an organometallic subunit next to a classical Werner-type subunit.

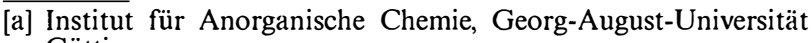
Göttingen

Tammanstraße 4, 37077 Göttingen, Germany

Fax: +49-551-393063

E-mail: franc.meyer@chemie.uni-goettingen.de

[b] Institut für Anorganische Chemie, Universität Regensburg

Universitätsstraße 31, 93040 Regensburg, Germany chemistry, oxidation of the heterobimetallic systems is highly localized at the organometallic manganese site. Structural and spectroscopic features as well as trends for the redox potentials of the $\mathrm{Mn}^{\mathrm{I}} / \mathrm{Mn}^{\mathrm{II}}$ couple suggest that ligand variations at the nickel(II) Werner-type subunit exert only a small influence on the properties of the organometallic part. In contrast, reduction occurs at the nickel site and is strongly dependent on the anion present. The effects at the organometallic $\mathrm{CpMn}(\mathrm{CO})_{2}$ subunit upon reduction of the proximate nickel ion are most pronounced for 5 .

We have recently reported a series of unsymmetrical homo- and heterobimetallic complexes of type $\mathbf{A}$ that formally combine an organometallic $\mathrm{CpMn}(\mathrm{CO})_{2}$ fragment $\mathbf{B}$ and a classical subunit of type $\mathbf{C}$ (Scheme 1). ${ }^{[6-8]}$ The latter is reminiscent of the tripodal tetradentate tris(pyridylmethyl)amine systems that are well established in mononuclear coordination chemistry. ${ }^{[9]}$ Manganese(II), cobalt(II), or zinc(II) ions with different co-ligands $\mathrm{X}$ can be accommodated in the Werner-type compartment of complexes A, with only subtle changes of the spectroscopic and redox properties of the organometallic site. ${ }^{[6-8]}$ It appears that the two metal ions in these complexes are electronically quite independent. In contrast, strong electronic coupling was observed in the symmetric dimanganese complex $\mathbf{D}$, which was shown to undergo two sequential metal-centered oneelectron oxidations with fast intramolecular thermal electron transfer $\left(k_{\mathrm{ET}} \approx 2.6 \times 10^{10} \mathrm{~s}^{-1}\right.$ at $\left.298 \mathrm{~K}\right)$ in the mixedvalent $\mathrm{Mn}^{\mathrm{I}} \mathrm{Mn}^{\mathrm{II}}$ species, which has a formal low-spin $\mathrm{d}^{5} \mathrm{~d}^{6}$ electronic configuration. ${ }^{[10]}$ The coincidence of the $\pi$ plane of the heterocycle with the mirror plane of the $\mathrm{Mn}(\mathrm{CO})_{2}$ moiety in $\mathbf{D}$ is an ideal arrangement for Mn-pyrazolate $\pi$ interactions and hence for electronic communication between the two Mn centers. ${ }^{[10-12]}$

In the present work we have now investigated a series of new heterobimetallic complexes of type $\mathbf{A}$ with nickel(II) in the tripodal tetradentate $\left\{\mathrm{N}_{4}\right\}$ coordination site and different counteranions Y. A large separation of the metalcentered redox potentials was anticipated for this particular combination since oxidation of the manganese ion might 

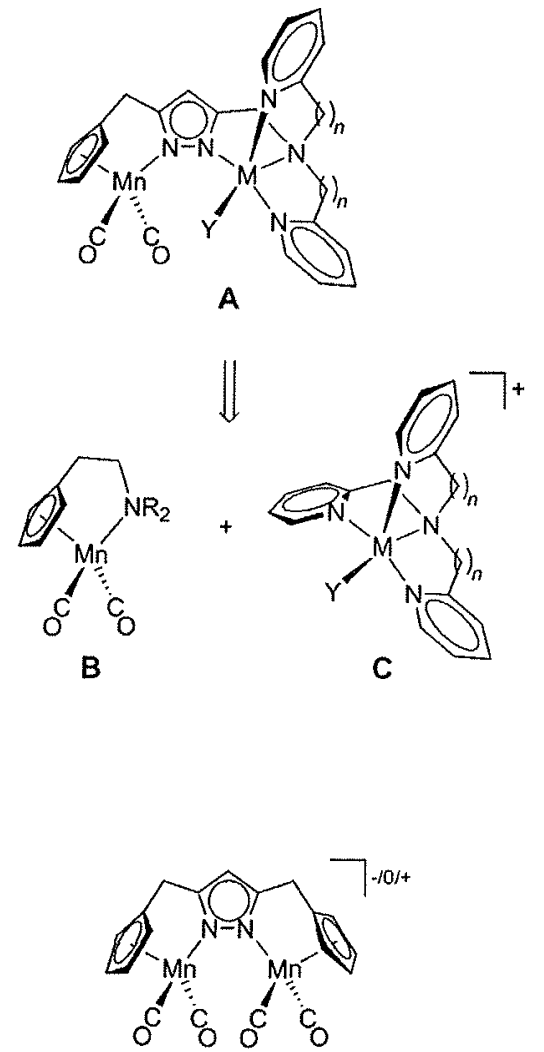

D

Scheme 1 .

occur easily while nickel(I) or nickel(III) should be much harder to access. It therefore appeared interesting to probe whether one-electron redox processes would be strictly confined to one site and to what extent a mutual influence of the adjacent metal ions might be discernible for the $\mathrm{Mn} / \mathrm{Ni}$ case.

\section{Results and Discussion}

Synthesis and Structural Characterization of the Complexes

Cymantrene derivatives 1 and $\mathbf{2}$ are the basic scaffolds for this particular class of heterobimetallic complexes (Scheme 2). They were prepared in several steps from simple pyrazole derivatives as reported previously, ${ }^{[6]}$ with different lengths of the pyridylalkyl side-arms appended to the pyrazole heterocycle. The latter variation allows us to probe the effect of small changes of the Werner-type $\left\{\mathrm{N}_{4}\right\}$ binding pockets on the properties of the bimetallic array. Photolysis of 1 or 2 with a high pressure mercury lamp in a quartz tube at $-40^{\circ} \mathrm{C}$ leads to $\mathrm{CO}$ release and intramolecular coordination of the pyrazole nitrogen atom to manganese, and subsequent deprotonation with one equivalent of $\mathrm{KO} t \mathrm{Bu}$ followed by addition of the appropriate nickel salt [Ni-
$\left(\mathrm{NO}_{3}\right)_{2} \cdot 6 \mathrm{H}_{2} \mathrm{O}$ or $\left.\mathrm{Ni}(\mathrm{OAc})_{2} \cdot 4 \mathrm{H}_{2} \mathrm{O}\right]$ fills the $\left\{\mathrm{N}_{4}\right\}$ donor compartment. This synthetic sequence is best carried out as a one-pot reaction.

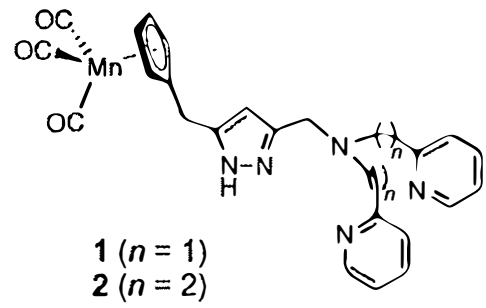

Scheme 2.

Single crystals of $\mathbf{3} \cdot \mathrm{dmf}, \mathbf{4}$, and 5 were obtained by slow diffusion of $\mathrm{Et}_{2} \mathrm{O}$ into $\mathrm{dmf}$ solutions of the products (Scheme 3), and details of the constitution of all three complexes were elucidated by $\mathrm{X}$-ray crystallography. The molecular structures are depicted in Figures 1, 2, and 3, together with selected interatomic distances and bond angles.

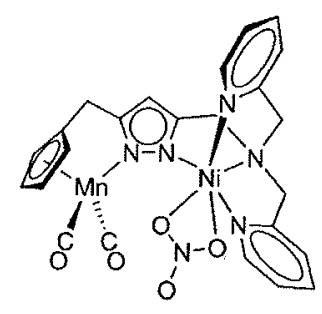

3

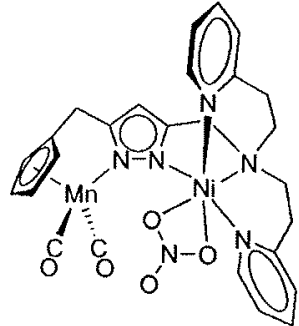

4

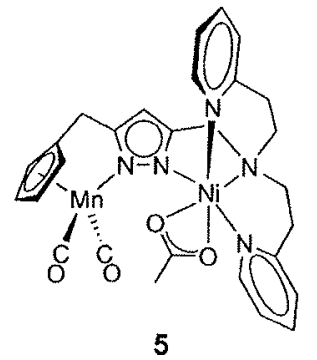

Scheme 3. Heterobimetallic $\mathrm{Mn} / \mathrm{Ni}$ complexes.

The pyrazolate bridges the two metal ions in all three complexes 3-5 and the nickel(II) is hosted in the classical $\left\{\mathrm{N}_{4}\right\}$ coordination site, as anticipated. Only complex 3 features crystallographically imposed mirror symmetry. Sixfold coordination of the nickel ion is completed by (slightly asymmetric) bidentate coordination of either a nitrate $(3,4)$ or acetate anion (5), which results in a strongly distorted octahedral environment of the metal center. The metalmetal separation depends strongly on the length of the ligand side-arms. Thus, a larger $\mathrm{Mn} \cdots \mathrm{Ni}$ distance of around $4.50 \AA$ is induced by the longer chelate arms in $\mathbf{4}$ and 5 whereas a distinctly shorter distance of $4.25 \AA$ is observed for 3. This variation is accompanied by different chelate arrangements of the Werner-type site: in the case of the shorter side-arms (3) the pyridyl nitrogens are located trans to each other and a nitrate oxygen is trans to the pyrazolate 


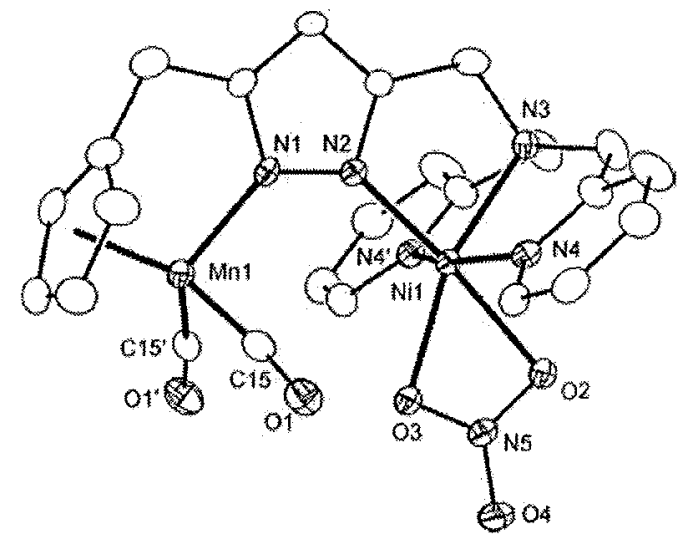

Figure 1. ORTEP plot (30\% probability thermal ellipsoids) of the molecular structure of 3. All hydrogen atoms have been omitted for the sake of clarity. Selected bond distances $[\AA]$ and angles $\left[^{\circ}\right]$ ( $\mathrm{Cgl}$ defines the centroid of the $\mathrm{Cp}$ ring atoms): $\mathrm{Mnl}-\mathrm{Cgl}$

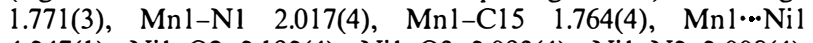
4.247(1), Nil-O2 2.192(4), Nil-O3 2.093(4), Nil-N2 2.008(4), Nil-N3 2.090(4), Nil-N4 2.064(3), Ol-C15 1.165(5); Cgl-MnlN1 111.9(2), Cgl-Mnl-Cl5 124.0(2), C15-Mn(1)-C15' 91.8(3), Cl5-Mnl-N1 100.1(2), Ol-Cl5-Mnl 174.1(3), N2-Nil-N3 84.5(2), N2-Nil-N4 94.5(1), N2-Nil-O2 174.1(2), N2-Nil-O3 113.3(2), N3-Nil-N4 82.1(1), N3-Nil-O2 101.5(2), N3-Nil-O3 162.2(2), N4-Nil-N4' 160.9(2), N4-Nil-O2 86.4(1), N4-Nil-O3 95.9(1), O2-Nil-O3 60.8(1). Symmetry transformation used to generate equivalent atoms: $\left({ }^{\prime}\right) x, 3 / 2-y, z$.

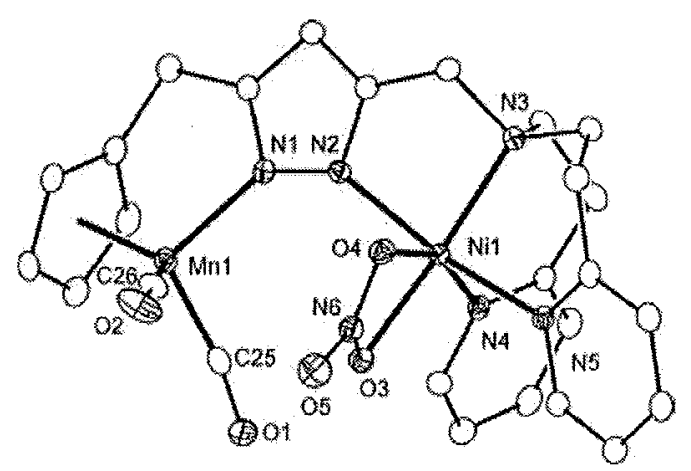

Figure 2. ORTEP plot (30\% probability thermal ellipsoids) of the molecular structure of 4 . All hydrogen atoms have been omitted for the sake of clarity. Selected bond distances $[\AA]$ and angles $\left[{ }^{\circ}\right]$ ( $\mathrm{Cgl}$ defines the centroid of the $\mathrm{Cp}$ ring atoms): $\mathrm{Mnl}-\mathrm{Cgl}$ 1.773(1), Mnl-N1 2.050(2), Mnl-C25 1.760(3), Mnl-C26

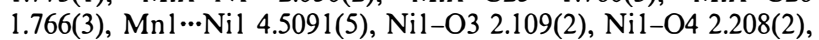
Nil-N2 2.100(2), Nil-N3 2.110(2), Nil-N4 2.058(2), Nil-N5 2.122(2), O1-C25 1.171(3), O2-C26 1.167(3); Cgl-Mnl-N1 112.8(1), Cgl-Mnl-C25 124.0(1), Cgl-Mnl-C26 123.7(1), C25Mn(1)-C26 90.3(1), C25-Mn1-N1 104.9(1), C26-Mn1-N1 95.9(1), O1-C25-Mnl 170.9(2), O2-C26-Mnl 174.9(2), N2-Ni1-N3 81.9(1), N2-Nil-N4 100.9(1), N2-Nil-N5 166.9(1), N2-Nil-O3 98.1(1), N2-Nil-O4 88.6(1), N3-Nil-N4 96.6(1), N3-Nil-N5 90.8(1), N3-Nil-O3 165.3(1), N3-Nil-O4 105.3(1), N4-Nil-N5 90.7(1), N4-Nil-O3 97.9(1), N4-Nil-O4 157.3(1), N5-Nil-O3 86.1(1), N5-Nil-O4 82.7(1), O3-Ni1-O4 60.1(1).

nitrogen, while for the longer side-arms $(4,5)$ the pyrazolate is found trans to a pyridine nitrogen. Similar features and differences of the $\mathrm{Mn} \cdots \mathrm{M}$ separation of approximately $0.3 \AA$ have been found for related $\mathrm{Mn} / \mathrm{Zn}$ and $\mathrm{Mn} / \mathrm{Co}$ com-

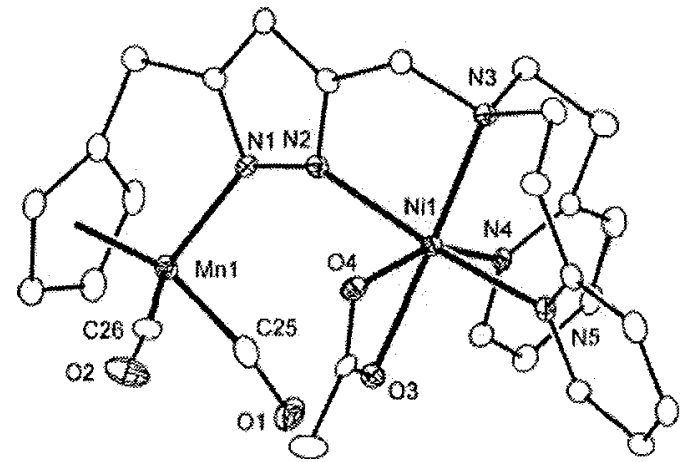

Figure 3. ORTEP plot (30\% probability thermal ellipsoids) of the molecular structure of $\mathbf{5}$. All hydrogen atoms have been omitted for the sake of clarity. Selected bond distances $[\AA]$ and angles $\left[^{\circ}\right]$ $[\mathrm{Cg}(1)$ defines the centroid of the $\mathrm{Cp}$ ring atoms]: $\mathrm{Mnl}-\mathrm{Cgl}$ 1.773(2), Mnl-N1 2.045(3), Mn1-C25 1.751(5), Mn1-C26

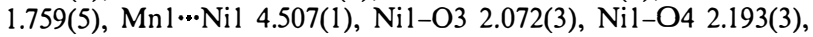
Nil-N2 2.118(3), Nil-N3 2.114(4), Nil-N4 2.075(3), Nil-N5 2.143(3), O1-C25 1.184(5), O2-C26 1.174(5); Cg1-Mn1-N1 112.7(1), Cgl-Mnl-C25 123.8(2), Cgl-Mnl-C26 123.9(2), C25$\mathrm{Mn}(1)-\mathrm{C} 26$ 90.3(2), C25-Mnl-N1 104.5(2), C26-Mnl-Nl 96.5(2), $\mathrm{O} 1-\mathrm{C} 25-\mathrm{Mnl}$ 171.2(4), O2-C26-Mnl 174.3(5), N2-Ni1-N3 81.5(1), N2-Nil-N4 101.0(1), N2-Nil-N5 166.0(1), N2-Nil-O3 100.2(1), N2-Nil-O4 89.0(1), N3-Nil-N4 95.9(1), N3-Nil-N5 89.9(1), N3-Nil-O3 166.6(1), N3-Nil-O4 105.0(1), N4-Nil-N5 90.8(1), N4-Nil-O3 96.8(1), N4-Nil-O4 158.0(1), N5-Nil-O3 85.7(1), N5-Nil-O4 82.5(1), O3-Nil-O4 61.9(1).

plexes with the same pyrazole-based ligands. ${ }^{[6,8]}$ The binding mode of the acetate or nitrate co-ligand (chelating, semi-chelating, or monodentate) depends on the radii and the particular stereoelectronic preferences of the metal ion in the $\left\{\mathrm{N}_{4}\right\}$ binding pocket.

The $\mathrm{Ni}-\mathrm{O} / \mathrm{N}$ bond lengths of 3-5 lie within the range usually reported for octahedral nickel(II) complexes with a comparable $\mathrm{N}_{4} \mathrm{O}_{2}$ coordination sphere. ${ }^{[13]}$ In particular, embedding of the nickel ion in the $\left\{\mathrm{N}_{4}\right\}$ pocket is reminiscent of the situation found for a mononuclear nickel(II) acetate complex of type $\mathbf{C}$ with the tripodal tetradentate tris(pyridylmethyl)amine (TPA) ligand E. ${ }^{[14]}$ This is in line with the description of complexes 3-5 as hybrids of an organometallic type $\mathbf{B}$ and a classical type $\mathbf{C}$ subunit. In the case of $\mathbf{E}$, however, the acetate co-ligand is only monodentate and the remaining coordination site is occupied by a water molecule.

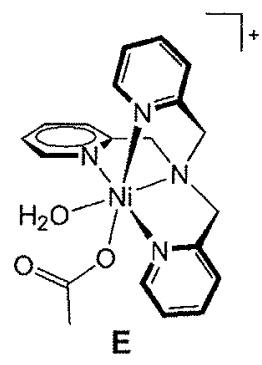

A comparison of the $\mathrm{Mn}-\mathrm{Cg}(\mathrm{Cg}$ defines the centroid of the ring atoms of the cyclopentadienido-anion), $\mathrm{Mn}-\mathrm{CO}$, $\mathrm{Mn}-\mathrm{N}$, and $\mathrm{C} \equiv \mathrm{O}$ bond lengths of $\mathbf{3}-\mathbf{5}$ and related $\mathrm{Mn} / \mathrm{Zn}$, 
Table 1. Comparison of selected bond lengths $[\AA]$ and angles [ $\left.{ }^{\circ}\right]$.

\begin{tabular}{|c|c|c|c|c|c|}
\hline & Mn only[6] & $\mathrm{Mn}^{2} \cdots \mathrm{Mn}^{[7]}$ & $\mathrm{Mn} \cdots \mathrm{Co}^{[8]}$ & $\mathrm{Mn} \cdots \mathrm{Zn}^{[6]}$ & $\mathrm{Mn} \cdots \mathrm{Ni}$ \\
\hline $\mathrm{Mn}-\mathrm{Cg}$ & 1.77 & $1.76-1.77$ & $1.76-1.77$ & 1.77 & 1.77 \\
\hline $\mathrm{Mn}-\mathrm{N}$ & $2.01-2.02$ & $2.01-2.03$ & $2.01-2.05$ & $1.99-2.03$ & $2.02-2.05$ \\
\hline $\mathrm{Mn}-\mathrm{CO}$ & $1.77-1.78$ & $1.76-1.78$ & $1.75-1.77$ & $1.76-1.77$ & $1.75-1.77$ \\
\hline $\mathrm{C} \equiv \mathrm{O}$ & $1.16-1.17$ & $1.16-1.17$ & $1.17-1.20$ & $1.16-1.19$ & $1.17-1.18$ \\
\hline $\mathrm{Cg}-\mathrm{Mn}-\mathrm{N}$ & 111.2 & $111.6-112.7$ & $112.1-112.5$ & $110.8-112.5$ & $111.9-112.8$ \\
\hline $\mathrm{Cg}-\mathrm{Mn}-\mathrm{CO}$ & $123.9-127.2$ & $121.2-126.0$ & $121.7-125.0$ & $122.4-128.3$ & $123.7-124.0$ \\
\hline $\mathrm{CO}-\mathrm{Mn}-\mathrm{CO}$ & $89.4-91.4$ & $91.4-92.8$ & $93.4-93.8$ & $90.3-93.2$ & $90.3-91.8$ \\
\hline $\mathrm{CO}-\mathrm{Mn}-\mathrm{N}$ & $96.0-102.2$ & $94.8-102.7$ & $99.5-104.1$ & $94.6-101.4$ & $95.9-104.9$ \\
\hline
\end{tabular}

$\mathrm{Mn} / \mathrm{Co}$, and $\mathrm{Mn} / \mathrm{Mn}$ complexes, as well as complexes where the $\left\{\mathrm{N}_{4}\right\}$ site is unoccupied, reveals that the choice of metal in the classical Werner-type site seems to have only a small influence on the bonding parameters of the organometallic $\mathrm{CpMn}(\mathrm{CO})_{2}$ site (Table 1). Only the CO-Mn-N angles appear to be somewhat flexible and span a range from $94.8^{\circ}$ to $104.1^{\circ}$ (Table 1 ).

In order to visualize the extent of preorganization and the flexibility of the dimetallic arrangement based on $\mathbf{1}$ and 2, a superposition of the pyrazolate-bridged cores of all $\mathrm{Mn} / \mathrm{Mn}, \mathrm{Mn} / \mathrm{Co}, \mathrm{Mn} / \mathrm{Ni}$, and $\mathrm{Mn} / \mathrm{Zn}$ dinuclear complexes with either short or long chelate arms is shown in Figure 4. Structural variations should reflect the conformational freedom of the pyrazolate-centered dimetallic array, with the metal ions swinging above and below the heterocyclic plane. It seems that the range of displacements out of the plane of the pyrazolate heterocycle that is accessible to the two metal ions is greater in the case of the longer (and more flexible) side-arms at the $\left\{\mathrm{N}_{4}\right\}$ compartment. The maximum angle between the pyrazolate plane and the N1-Mn bond is $11.1^{\circ}$ for systems derived from 1 and $22.5^{\circ}$ for systems derived from 2 ; the maximum angle between the pyrazolate plane and the N2-M bond is $14.5^{\circ}$ for systems derived from 1 and $17.9^{\circ}$ for systems derived from 2 .

\section{Spectroscopic and Electrochemical Trends}

All $\mathrm{Mn} / \mathrm{Ni}$ complexes show two strong IR bands of similar relative intensities for the $v_{a s}(\mathrm{CO})$ and $v_{\mathrm{s}}(\mathrm{CO})$ vibrations of the $\left\{\mathrm{Mn}(\mathrm{CO})_{2}\right\}$ fragment at around 1900 and $1825 \mathrm{~cm}^{-1}$, respectively (Table 2 ). Neither the chelate ring size of the $\left\{\mathrm{N}_{4}\right\}$ ligand compartment (3 vs. 4) nor the coligand at nickel (nitrate in 4 vs. acetate in 5) seem to have any considerable effect on the energies of the $\mathrm{CO}$ stretches. Complex 5 features strong bands at 1550 and $1447 \mathrm{~cm}^{-1}$ that are absent in the spectrum of $\mathbf{4}$ and are thus assigned to the acetate ligand. The small difference between $v_{\mathrm{as}}(\mathrm{COO})$ and $v_{\mathrm{s}}(\mathrm{COO})$ is in accordance with bidentate acetate coordination. ${ }^{[15]}$

Cyclic voltammograms in $\operatorname{MeCN}(3)$ or $\operatorname{dmf}(4,5)$ solution feature a reversible redox wave in the range $E_{1 / 2}=$ -0.50 to $-0.66 \mathrm{~V}$ and an irreversible reduction at much lower potential (Table 3). ${ }^{[16]}$ The cyclic voltammograms of 4 and 5 depicted in Figures 5 and 6, respectively, show that variations in the co-ligand at nickel (nitrate in 4 vs. acetate in 5) barely influence the first redox process at around
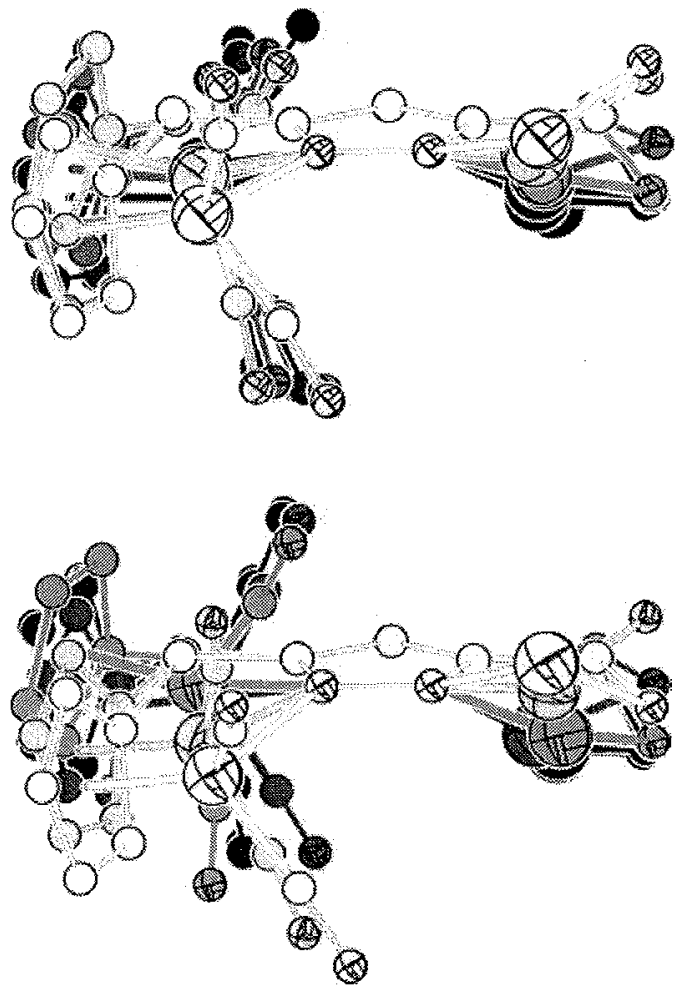

Figure 4. Overlay of the pyrazolate-bridged heterobimetallic arrangements for the series of $\mathrm{Mn} / \mathrm{Mn}, \mathrm{Mn} / \mathrm{Co}, \mathrm{Mn} / \mathrm{Ni}$, and $\mathrm{Mn} / \mathrm{Zn}$ complexes based on 1 (short chelate arms; top) or 2 (long chelate arms; bottom). The appended chelate arms and the co-ligands at the Werner-type site have been omitted for clarity.

Table 2. IR absorptions $\left[\mathrm{cm}^{-1}\right]$ in the $\mathrm{CO}$ stretching range.

\begin{tabular}{lcc}
\hline & dce solution & KBr \\
\hline $\mathbf{3}$ & 1902,1825 & 1902,1822 \\
$\mathbf{3}^{+}$ & 2029,1949 & \\
$\mathbf{4}^{+}$ & 1906,1829 & 1906,1822 \\
$\mathbf{4}^{+}$ & 2029,1950 & 1890,1823 \\
$\mathbf{5}^{+}$ & 1904,1827 & \\
\hline
\end{tabular}

[a] dœe $=1,2$-dichloroethane.

$-0.6 \mathrm{~V}$ but have a pronounced effect on the reduction at lower potential. The former is thus assigned to the $\mathrm{Mn}^{\mathrm{I}} /$ $\mathrm{Mn}^{\mathrm{II}}$ couple while the latter process likely corresponds to the $\mathrm{Ni}^{\mathrm{II}} \rightarrow \mathrm{Ni}^{\mathrm{I}}$ reduction. Potentials for the $\mathrm{Mn}^{\mathrm{I}} / \mathrm{Mn}^{\mathrm{II}}$ interconversions of $\left[\mathrm{CpMn}(\mathrm{CO})_{2} \mathrm{~L}\right]$ complexes are known to 
vary over a potential range of more than $2 \mathrm{~V}$, depending of the nature of the ligand L. ${ }^{[1,12,17]}$ The rather low oxidation potentials of 3-5 indicate significant stabilization of the $\mathrm{Mn}^{\mathrm{II}}$ state by the anionic pyrazolate ligand and reflect the high nucleophilicity of the nitrogen heterocycle in these heterobimetallic species. ${ }^{[17]}$ Small influences of the ligand chelate ring size ( 3 vs. 4 ) or of the co-ligand at nickel (4 vs. 5 ) on the $\mathrm{Mn}^{\mathrm{I}} / \mathrm{Mn}^{\mathrm{II}}$ redox potential suggest a certain degree of electronic communication between the proximate metal ions. For example, the oxidation wave of the nitrate complex with shorter chelate arms at nickel (3) is shifted anodically by $60 \mathrm{mV}$ with respect to the congener with longer chelate arms (4), and the more electron-donating acetate at nickel facilitates oxidation of the manganese site by $100 \mathrm{mV}$ (5 vs. 4). These trends are in good agreement with findings for the related $\mathrm{Mn} / \mathrm{Mn}, \mathrm{Mn} / \mathrm{Co}$, and $\mathrm{Mn} / \mathrm{Zn}$ systems. ${ }^{[6-8]}$

Table 3. Formal potentials for the $\mathrm{Mn}^{\mathrm{T}} / \mathrm{Mn}^{\mathrm{II}}$ couple in $\mathrm{MeCN} / 0.1 \mathrm{M}$ $n \mathrm{Bu}_{4} \mathrm{NClO}_{4}(3)$ or $\mathrm{dmf} / 0.1 \mathrm{M} n \mathrm{Bu}_{4} \mathrm{NPF}_{6}(4,5) .^{[16]}$

\begin{tabular}{ccc}
\hline Complex & $E_{1 / 2}\left(\mathrm{Mn}^{\mathrm{I}} \mathrm{Ni}^{\mathrm{II}} / \mathrm{Mn}^{\mathrm{II}} \mathrm{Ni}^{\mathrm{II}}\right)$ & $E_{\mathrm{red}}^{\mathrm{p}}\left(\mathrm{Mn}^{\mathrm{r}} \mathrm{Ni}^{\mathrm{II}} / \mathrm{Mn}^{\mathrm{I}} \mathrm{Ni}^{\mathrm{l}}\right)$ \\
\hline $\mathbf{3}$ & -0.50 & $-1.70^{[\mathrm{a}]}$ \\
$\mathbf{4}$ & -0.56 & $-1.83^{[\mathrm{al}]}$ \\
$\mathbf{5}$ & -0.66 & $-2.72^{[\mathrm{a}]}$ \\
\hline
\end{tabular}

[a] Peak potentials for irreversible reduction process at $100 \mathrm{mV} \mathrm{s}^{-1}$.

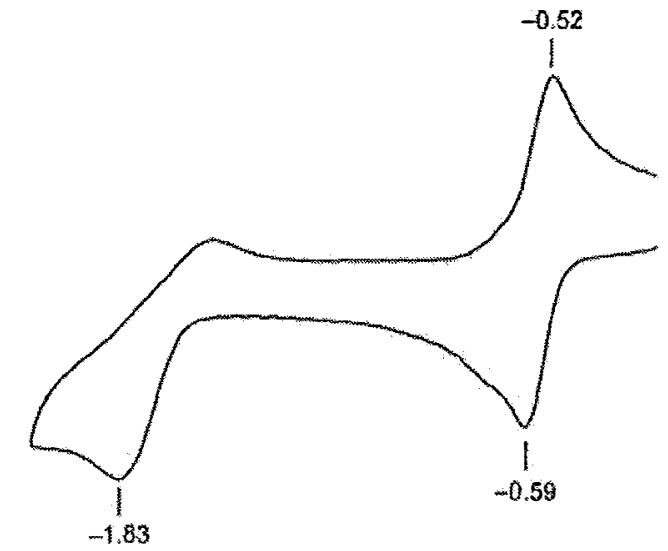

$$
\begin{aligned}
& \begin{array}{lllllllllll}
-2.2 & -2.0 & -1.8 & -1.6 & -1.4 & -1.2 & -1.0 & -0.8 & -0.6 & -0.4 & -0.2
\end{array} \\
& \text { EN) }
\end{aligned}
$$

Figure 5. Cyclic voltammogram of $\mathbf{4}$ recorded with a platinum electrode in dmf containing approximately $0.1 \mathrm{M} n \mathrm{Bu}_{4} \mathrm{NPF}_{6}$; scan speed: $100 \mathrm{mV} \mathrm{s}^{-1}$; potentials are given in volts vs. the $\mathrm{Fc} / \mathrm{Fc}^{+}$couple.

IR and UV/Vis spectroelectrochemistry have proven valuable for establishing the site of redox processes in such heterobimetallic complexes and to characterize the resulting species. Oxidation of the $\mathrm{Mn} / \mathrm{Ni}$ systems 3-5 in 1,2-dichloroethane (dce) was thus followed by IR and UV/Vis spectroscopy in an OTTLE cell (Figures 7 and 8, and Figures S1-S4 in the Supporting Information). The intensity of the pair of CO stretching vibrations at around 1905 and $1825 \mathrm{~cm}^{-1}$ decreases at the expense of two new bands at around 2030 and $1950 \mathrm{~cm}^{-1}$ upon gradual electrolysis, thus confirming the structural integrity of the $\mathrm{CpMn}(\mathrm{CO})_{2}$ frag-

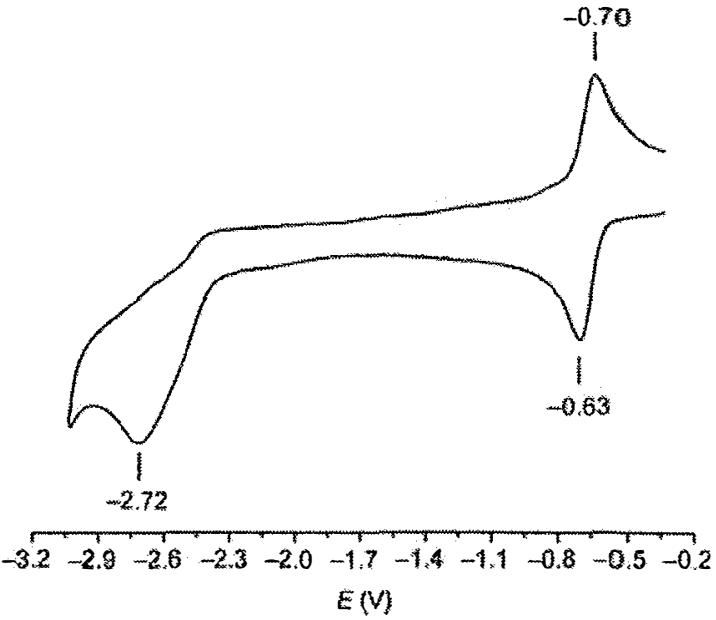

Figure 6. Cyclic voltammogram of 5 recorded with a platinum electrode in $\mathrm{dmf}$ containing approximately $0.1 \mathrm{M} n \mathrm{Bu}_{4} \mathrm{NPF}_{6}$; scan speed: $100 \mathrm{mV} \mathrm{s}^{-1}$; potentials are given in volts vs. the $\mathrm{Fc} / \mathrm{Fc}^{+}$couple.

ment upon generation of the oxidized species $3^{+}-5^{+}$. The slightly lower intensity of the new bands is in agreement with our expectations since spectral intensities in $\mathrm{M}-\mathrm{CO}$ moieties usually decrease with increasing oxidation state. ${ }^{[8]}$ The shift of about $125 \mathrm{~cm}^{-1}$ to higher frequencies is very similar to the shift observed in the corresponding $\mathrm{Mn} / \mathrm{Zn}$, $\mathrm{Mn} / \mathrm{Co}$ and $\mathrm{Mn} / \mathrm{Mn}$ complexes. ${ }^{[6-8]}$ It is typical for a oneunit increase in the oxidation state of the metal ion and reflects the diminished backbonding ability in the oxidized $\mathrm{CpMn}^{\mathrm{II}}(\mathrm{CO})_{2}$ subunit. This confirms that the anodic process in the present $\mathrm{Mn} / \mathrm{Ni}$ systems is fully localized at the organometallic site, which means that nickel remains in the + II oxidation state. The presence of several isosbestic points confirms clean conversion between the $\mathrm{Mn}^{\mathrm{I}} \mathrm{Ni}^{\mathrm{II}}$ and $\mathrm{Mn}^{\mathrm{II}}$ $\mathrm{Ni}^{\mathrm{II}}$ species. However, the original spectra of the starting materials 3-5 are not fully restored upon re-reduction. Furthermore, the intensities of the $\mathrm{CO}$ stretching vibrations

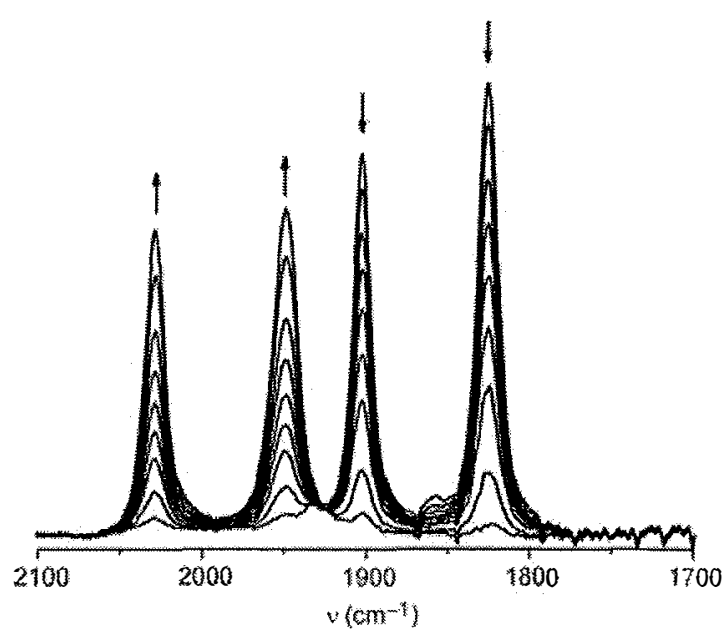

Figure 7. IR spectroscopic changes during the gradual oxidation of 3 in dce/n $n \mathrm{Bu}_{4} \mathrm{PF}_{6}$ solution in an OTTLE cell. 
are somewhat lower than their original values, which suggests that the oxidized complexes have only limited stabilities in solution. Accordingly, attempts to crystallize the $\mathrm{Mn}^{\mathrm{II}} \mathrm{Ni}^{\mathrm{II}}$ complexes after chemical oxidation have so far proved unsuccessful.

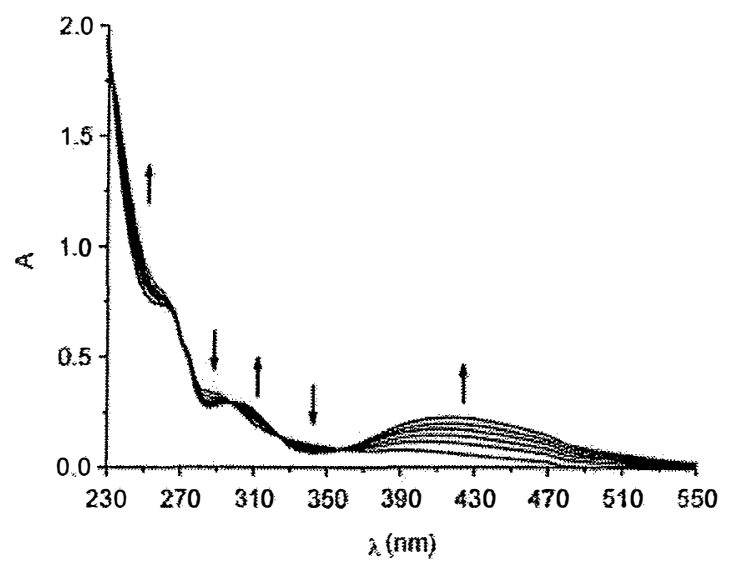

Figure 8. UV/Vis spectroscopic changes during the gradual oxidation of 3 in dce/n $/ \mathrm{Bu}_{4} \mathrm{PF}_{6}$ solution in an OTTLE cell.

The oxidation of $\mathbf{3 - 5}$ is accompanied in UV/Vis spectroelectrochemistry by the appearance of a new band peaking in the range $395-421 \mathrm{~nm} \mathrm{(3:} 415 \mathrm{~nm} ; 4: 396 \mathrm{~nm}$;: $421 \mathrm{~nm}$, Figure 8 and S3, S4). The rise of a similar band at about $400 \mathrm{~nm}$ has also been observed upon oxidation of the corresponding $\mathrm{Mn} / \mathrm{Zn}, \mathrm{Mn} / \mathrm{Co}$ and $\mathrm{Mn} / \mathrm{Mn}$ systems ${ }^{[6-8]}$ and can

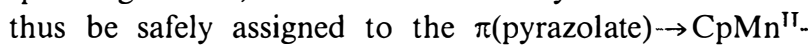
$(\mathrm{CO})_{2}$ LMCT transition, which is obviously relatively insensitive to the identity of the metal ion within the adjacent Werner-type $\left\{\mathrm{N}_{4}\right\}$ compartment.

According to IR spectroelectrochemistry, reduction of $\mathbf{4}$ is also an almost reversible process. Shifts to lower energy in the CO stretching range are only minor (Figures 9 and $10 ; 1906 / 1829 \rightarrow 1902 / 1827 \mathrm{~cm}^{-1}$ for $4 ; 1906 / 1829 \rightarrow 1896 /$ $1819 \mathrm{~cm}^{-1}$ for 5), in accordance with the idea that reduction occurs within the nickel subunit. It is interesting to note, however, that the $\mathrm{CO}$ stretches are clearly more affected in 5 , where a noticeable shift of $10 \mathrm{~cm}^{-1}$ is observed compared to an almost negligible shift of about $3 \mathrm{~cm}^{-1}$ for 4 . Since 4 and $\mathbf{5}$ are derived from the same pyrazolate-based ligand scaffold, this distinction must stem solely from the different anion at nickel (nitrate vs. acetate). Re-oxidation of $5^{-}$does not reproduce the original spectrum but gives rise to a new species with two IR bands that are shifted by $18 \mathrm{~cm}^{-1}$ to lower energy with respect to the $\mathrm{CO}$ absorptions of 5 . While the typical pattern of two $\mathrm{CO}$ stretches suggests that the integrity of the $\mathrm{CpMn}(\mathrm{CO})_{2}$ subunit is retained, the chemical reaction that apparently follows upon electrochemical reduction may involve a ligand exchange at nickel or ligand fragmentation at the Werner-type site. The rather different behavior of $\mathbf{4}$ and $\mathbf{5}$ upon reduction is in accordance with the strongly different reduction potentials determined electrochemically for these two complexes (compare Figures 5 and 6).

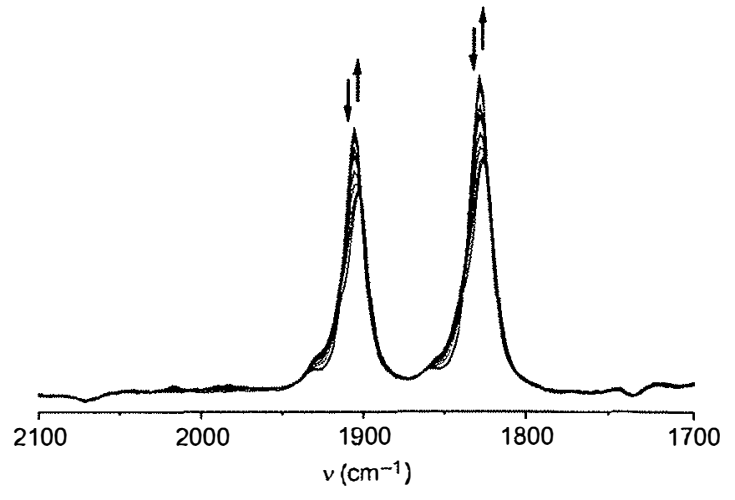

Figure 9. IR spectroscopic changes during the gradual reduction of 4 in dceln $\mathrm{Bu}_{4} \mathrm{PF}_{6}$ solution in an OTTLE cell.

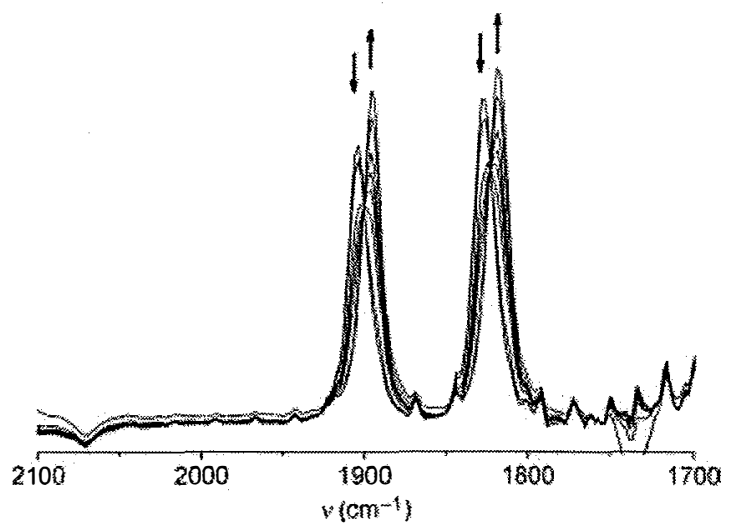

Figure 10. IR spectroscopic changes during the gradual reduction of 5 in dce $/ n \mathrm{Bu}_{4} \mathrm{PF}_{6}$ solution in an OTTLE cell.

\section{Conclusions}

The present set of $\mathrm{Mn} / \mathrm{Ni}$ complexes complements a series of unique heterobimetallic systems in which an organometallic $\mathrm{CpMn}(\mathrm{CO})_{2}$ fragment is bridged via a pyrazolate to a nearby metal ion $\left(\mathrm{Mn}^{2+}, \mathrm{Co}^{2+}, \mathrm{Ni}^{2+}, \mathrm{Zn}^{2+}\right)$ that is nested in a classical Werner-type compartment with an $\left\{\mathrm{N}_{4}\right\}$ donor set. The pronounced asymmetry of the bimetallic array results in strong localization of redox events in those systems: oxidation occurs at relatively low potential and is strictly confined to the organometallic site, while reduction (in the case of $\mathrm{Mn}^{2+}, \mathrm{Co}^{2+}$, or $\mathrm{Ni}^{2+}$ as the second metal ion) appears to occur solely within the Werner-type subunit, with very little mutual interaction. Ligand variations at the $\left\{\mathrm{N}_{4}\right\}$ compartment (such as different lengths of the chelate arms or different co-ligands) exert only minor influences on the $\mathrm{CpMn}(\mathrm{CO})_{2}$ fragment, but have a clear effect on the properties of the second metal ion, as expected. Further modifications of the Werner-type subunit, including donor sets other than the tripodal tetradentate $\left\{\mathrm{N}_{4}\right\}$ motif of the present complexes, should allow us to shift the redox potential of the second metal ion closer to that of the organometallic $\mathrm{Mn}$ site. It will be interesting to monitor the changes of intermetallic communication that might accompany such modifications and to probe the co- 
operative redox transformation of substrates that bind to the second metal but exploit the strong reduction potential of the nearby organometallic site.

\section{Experimental Section}

General Procedures and Methods: Manipulations were carried out under an atmosphere of dry nitrogen by employing standard Schlenk techniques. Complexes $\mathbf{1}$ and $\mathbf{2}$ were prepared as reported previously. ${ }^{[6]}$ Solvents were dried according to established procedures. All other chemicals were obtained from commercial sources and used as received. IR spectra were recorded for $\mathrm{KBr}$ pellets with a Digilab Excalibur. ESI mass spectra were measured with a Finnigan MAT LCQ spectrometer. Elemental analyses were performed by the analytical laboratory of the Institut für Anorganische Chemie der Universität Göttingen using a Heraeus CHNO-RAPID instrument. Cyclic voltammetry was carried out with a Perkin-Elmer Model 263A potentiostat/galvanostat with glassy carbon working electrode and platinum reference and counter electrodes, in $0.1 \mathrm{M} n \mathrm{Bu}_{4} \mathrm{NClO}_{4} / \mathrm{CH}_{3} \mathrm{CN}$ or $0.1 \mathrm{M} n \mathrm{Bu}_{4} \mathrm{NPF}_{6} / \mathrm{dmf}$; ferrocene (the potential in $\mathrm{dmf}$ being $0.45 \mathrm{~V}$ against $\mathrm{SCE}$ ) ${ }^{[19]}$ was used as internal standard. Spectroelectrochemistry (IR and UV/Vis) was performed with a self-constructed OTTLE cell comprising a Ptmesh working and counter electrode and a silver wire as pseudeoreference electrode sandwiched in between the $\mathrm{CaF}_{2}$ windows of a conventional liquid IR cell. The working electrode is positioned in the center of the spectrometer beam with all other parts of the cell made non-transparent to the incident beam by means of an absorbing tape. ${ }^{[20]}$

Synthesis of Complex 3: A solution of $1(0.256 \mathrm{~g}, 0.52 \mathrm{mmol})$ in thf $(200 \mathrm{~mL})$ was irradiated with a high-pressure mercury lamp in a quartz tube at $-40^{\circ} \mathrm{C}$. Within one hour the color of the solution had changed from light yellow to yellow. The solution was then warmed to room temperature and $\mathrm{KO} t \mathrm{Bu}(0.058 \mathrm{~g}, 0.52 \mathrm{mmol})$ and $\mathrm{Ni}\left(\mathrm{NO}_{3}\right)_{2} \cdot 6 \mathrm{H}_{2} \mathrm{O}(0.151 \mathrm{~g}, 0.52 \mathrm{mmol})$ were added. The reaction mixture was stirred overnight to produce a yellow precipitate, which was separated by filtration, washed with light petroleum ether, and dried under vacuum. Single crystals were obtained after several days by slow diffusion of diethyl ether into a concentrated $\mathrm{dmf}$ solution of the crude product. The crystals were separated by filtration, washed with diethyl ether, and dried under vacuum. Yield: $31 \mathrm{mg}$ (9\%). IR (KBr): $\tilde{v}=2929$ (w), 2869 (w), 1902 (vs), 1822 (vs), $1672(\mathrm{~m}), 1605(\mathrm{~m}), 1479(\mathrm{~m}), 1384(\mathrm{~m}), 1287(\mathrm{~m}), 1157$ (w), $1097(w), 1056(w), 1024(w), 958(w), 884(w), 818(w), 771$ $(\mathrm{m}), 653(\mathrm{w}), 611(\mathrm{w}), 588(\mathrm{w}), 512(\mathrm{w}), 474(\mathrm{w}), 427(\mathrm{w}) \mathrm{cm}^{-1}$. $\mathrm{C}_{27} \mathrm{H}_{28} \mathrm{MnN}_{7} \mathrm{NiO}_{6}(660.2)$ : calcd. C 49.12, $\mathrm{H}$ 4.27, $\mathrm{N}$ 14.85; found C 49.27, H 4.44, N 13.98.

Synthesis of Complex 4: A solution of $2(0.230 \mathrm{~g}, 0.44 \mathrm{mmol})$ in thf $(200 \mathrm{~mL})$ was irradiated with a high pressure mercury lamp in a quartz tube at $-40^{\circ} \mathrm{C}$. Within about one hour the color of the solution had changed from light yellow to yellow. The solution was then warmed to room temperature and $\mathrm{KO} t \mathrm{Bu}(0.049 \mathrm{~g}$, $0.44 \mathrm{mmol})$ and $\mathrm{Ni}\left(\mathrm{NO}_{3}\right)_{2} \cdot 6 \mathrm{H}_{2} \mathrm{O}(0.128 \mathrm{~g}, 0.44 \mathrm{mmol})$ were added. The reaction mixture was stirred overnight to produce a yellow precipitate, which was separated by filtration, washed with light petroleum, and dried under vacuum. Single crystals were obtained after several days by slow diffusion of diethyl ether into a concentrated dmf solution of the crude product. The crystals were separated by filtration, washed with diethyl ether, and dried under vacuum. Yield: $40 \mathrm{mg}(15 \%)$. IR (KBr): $\tilde{v}=2963(\mathrm{w}), 2916(\mathrm{w}), 2864$ (w), 1906 (vs), 1822 (vs), $1662(\mathrm{w}), 1607$ (m), $1578(\mathrm{w}), 1487(\mathrm{~m})$, $1451(\mathrm{~m}), 1387(\mathrm{~m}), 1340(\mathrm{w}), 1276(\mathrm{~m}), 1155(\mathrm{w}), 1105(\mathrm{~m}), 1052$ (w), $1022(\mathrm{~m}), 950(\mathrm{w}), 807(\mathrm{w}), 765(\mathrm{~m}), 656(\mathrm{w}), 591(\mathrm{w}), 528(\mathrm{w})$, 474 (w), 432 (w) $\mathrm{cm}^{-1}$. HR-MS (ESI+, MeCN): $\mathrm{m} / \mathrm{z}$ calcd. for $\mathrm{C}_{26} \mathrm{H}_{25} \mathrm{MnN}_{6} \mathrm{NiO}_{5}[\mathrm{M}]^{+}$: 614.06149; found 614.06132. $\mathrm{C}_{26} \mathrm{H}_{25} \mathrm{MnN}_{6} \mathrm{NiO}_{5}$ (615.2): calcd. C 50.77, $\mathrm{H}$ 4.10, $\mathrm{N}$ 13.66; found C 49.50, H 4.27, N 13.62 .

Synthesis of Complex 5: A solution of $2(0.200 \mathrm{~g}, 0.38 \mathrm{mmol})$ in thf $(200 \mathrm{~mL})$ was irradiated with a high pressure mercury lamp in a quartz tube at $-40^{\circ} \mathrm{C}$. Within about one hour the color of the solution had changed from light yellow to yellow. The solution was

Table 4. Crystal data and refinement details for $\mathbf{3}, \mathbf{4}$, and $\mathbf{5}$.

\begin{tabular}{|c|c|c|c|}
\hline & $3 \cdot \mathrm{dmf}$ & 4 & 5 \\
\hline $\begin{array}{l}\text { Formula } \\
M_{\text {r }}\end{array}$ & $\begin{array}{l}\mathrm{C}_{24} \mathrm{H}_{21} \mathrm{MnN}_{6} \mathrm{NiO}_{5}, \mathrm{C}_{3} \mathrm{H}_{7} \mathrm{NO} \\
660.21\end{array}$ & $\begin{array}{l}\mathrm{C}_{26} \mathrm{H}_{25} \mathrm{MnN}_{6} \mathrm{NiO}_{5} \\
615.17\end{array}$ & $\begin{array}{l}\mathrm{C}_{28} \mathrm{H}_{28} \mathrm{MnN}_{5} \mathrm{NiO}_{4} \\
612.20\end{array}$ \\
\hline Crystal size $[\mathrm{mm}]$ & $0.38 \times 0.25 \times 0.15$ & $0.49 \times 0.31 \times 0.20$ & $0.20 \times 0.13 \times 0.08$ \\
\hline Crystal system & monoclinic & monoclinic & monoclinic \\
\hline Space group & $P 2_{1} / m$ (no. 11$)$ & $P 2_{1} / n($ no. 14$)$ & $P 2_{1} / n($ no. 14$)$ \\
\hline$a[\AA]]$ & $8.2387(6)$ & $9.8289(6)$ & $9.8625(8)$ \\
\hline$b[\AA]$ & $16.1559(8)$ & $21.7710(15)$ & $22.0007(18)$ \\
\hline$c[\AA]$ & $11.2310(7)$ & $11.8129(7)$ & $12.1508(11)$ \\
\hline$\beta\left[^{\circ}\right]$ & $107.879(5)$ & $99.659(5)$ & $101.311(7)$ \\
\hline$V\left[\hat{A}^{3}\right]$ & $1422.69(15)$ & $2491.9(3)$ & $2585.3(4)$ \\
\hline$Z$ & 2 & 4 & 4 \\
\hline$\rho_{\text {calcd. }}\left[\mathrm{g} \mathrm{cm}^{-3}\right]$ & 1.541 & 1.640 & 1.573 \\
\hline$F(000)$ & 680 & 1264 & 1264 \\
\hline$\mu\left[\mathrm{mm}^{-1}\right]$ & 1.160 & 1.314 & 1.262 \\
\hline$T_{\max } / T_{\min }$ & $0.8422 / 0.6728$ & $0.7909 / 0.6217$ & $0.8754 / 0.6491$ \\
\hline$h \mathrm{kl}$ range & $\pm 9, \pm 18, \pm 13$ & $\pm 11,-25$ to $24, \pm 13$ & -11 to $10, \pm 25, \pm 14$ \\
\hline$\theta$ range $\left[{ }^{\circ}\right]$ & $1.91-24.69$ & $1.87-24.83$ & $1.85-24.81$ \\
\hline Measured reflections & 23598 & 15798 & 13272 \\
\hline Unique reflections $\left[R_{\mathrm{int}}\right]$ & $2516[0.0641]$ & $4270[0.0405]$ & 4434 [0.0993] \\
\hline Observed reflections $I>2 \sigma(I)$ & 2159 & 3460 & 2844 \\
\hline Data/restraints/parameters & $2516 / 2 / 210$ & $4270 / 0 / 352$ & $4434 / 0 / 353$ \\
\hline Goodness-of-fit & 1.066 & 1.002 & 1.005 \\
\hline$R 1[I>2 \sigma(I)]$ & 0.0498 & 0.0293 & 0.0492 \\
\hline$w R 2$ (all data) & 0.1480 & 0.0706 & 0.0669 \\
\hline Residual electron density $\left[\mathrm{e} \AA^{-3}\right]$ & $1.505 /-0.538$ & $0.313,-0.320$ & $0.451 /-0.401$ \\
\hline
\end{tabular}


then warmed to room temperature and $\mathrm{KO} t \mathrm{Bu} \quad(0.043 \mathrm{~g}$, $0.38 \mathrm{mmol})$ and $\mathrm{Ni}\left(\mathrm{CH}_{3} \mathrm{COO}\right)_{2} \cdot 4 \mathrm{H}_{2} \mathrm{O}(0.095 \mathrm{~g}, 0.38 \mathrm{mmol})$ were added. The reaction mixture was stirred overnight to produce a yellow precipitate, which was separated by filtration, washed with light petroleum, and dried under vacuum. Single crystals were obtained after several days by slow diffusion of diethyl ether into a concentrated dmf solution of the crude product. The crystals were separated by filtration, washed with diethyl ether, and dried under vacuum. Yield: $36 \mathrm{mg}(16 \%)$. IR $(\mathrm{KBr}): \tilde{v}=2964(\mathrm{w}), 2917(\mathrm{~m})$, 2861 (w), 1890 (vs), 1823 (vs), $1666(\mathrm{~m}), 1607$ (m), $1550(\mathrm{~m}), 1478$ $(\mathrm{m}), 1447(\mathrm{~m}), 1335(\mathrm{~m}), 1259(\mathrm{~m}), 1208(\mathrm{w}), 1148(\mathrm{w}), 1107(\mathrm{~m})$, $1052(\mathrm{~m}), 1021(\mathrm{~m}), 950(\mathrm{w}), 896(\mathrm{w}), 812(\mathrm{~m}), 771(\mathrm{~m}), 668(\mathrm{w})$, $608(\mathrm{w}), 528(\mathrm{w}), 467(\mathrm{w}), 433(\mathrm{w}), 410(\mathrm{w}) \mathrm{cm}^{-1}$. HR-MS (ESI+, MeCN): $m / z$ calcd. for $\mathrm{C}_{28} \mathrm{H}_{28} \mathrm{MnN}_{5} \mathrm{NiO}_{4}[\mathrm{M}]^{+}: 611.08698$; found 611.08634. $\mathrm{C}_{28} \mathrm{H}_{28} \mathrm{MnN}_{5} \mathrm{NiO}_{4}$ (612.2): calcd. C 54.93, $\mathrm{H}$ 4.61, N 11.44; found C 53.91, H 4.70, N 11.36 .

X-ray Crystallography of Complexes 3-5: X-ray data were collected with a STOE IPDS II diffractometer (graphite-monochromated Mo- $K_{\alpha}$ radiation, $\lambda=0.71073 \AA$ ) using the $\omega$-scans technique at $-140^{\circ} \mathrm{C}$ (Table 4). The structures were solved by direct methods and refined on $F^{2}$ using all reflections with SHELX-97. ${ }^{[2]]}$ The nonhydrogen atoms were refined anisotropically. Hydrogen atoms were placed in calculated positions and assigned an isotropic displacement parameter of $0.08 \AA^{2}$. Face-indexed absorption corrections were performed numerically with the program X-RED. ${ }^{[22]}$ The geometrical aspects of the structures were analyzed with the PLATON program. ${ }^{[23]}$ The $\mathrm{dmf}$ solvent molecule in $\mathbf{3} \cdot \mathrm{dmf}$ was found to be disordered about a center of inversion and was refined at half occupancy.

CCDC-638867 (for 3·dmf), -638868 (for 4), and -638869 (for 5) contain the supplementary crystallographic data for this paper. These data can be obtained free of charge from The Cambridge Crystallographic Data Centre via www.ccdc.cam.ac.uk/ data_request/cif.

Supporting Information (see also the footnote on the first page of this article): IR spectroscopic changes during gradual oxidation $4 \rightarrow 4^{+}$and $5 \rightarrow 5^{+}$in dce $/ n \mathrm{Bu}_{4} \mathrm{PF}_{6}$ solution in an OTTLE cell (Figures $\mathrm{S} 1$ and $\mathrm{S} 2$ ); $\mathrm{UV} / \mathrm{V}$ is spectroscopic changes during gradual oxidation $\mathbf{4} \rightarrow \mathbf{4}^{+}$and $\mathbf{5} \rightarrow \mathbf{5}^{+}$in dce $/ n \mathrm{Bu}_{4} \mathrm{PF}_{6}$ solution in an OTTLE cell (Figures S3 and S4).

\section{Acknowledgments}

Support by the Alexander von Humboldt foundation (research fellowship to H. Z.) is gratefully acknowledged. We thank J. Teichgräber for performing the $\mathrm{CV}$ measurements.

[1] a) S. Trofimenko, Progr: Inorg. Chem. 1986, 34, 115-210; b) G. La Monica, G. A. Ardizzoia, Progr: Inorg. Chem. 1997, 46,
151-238; c) R. Mukherjee, Coord. Chem. Rev. 2000, 203, 151218.

[2] C. Incarvito, A. L. Rheingold, A. L. Gavrilova, C. J. Qin, B. Bosnich, Inorg. Chem. 2001, 40, 1386-1390.

[3] J. Klingele, S. Dechert, F. Meyer, Coord. Chem. Rev., manuscript in preparation.

[4] a) D. E. Fenton, H. Okawa, Chem. Ber/Recueil 1997, 130, 433442; b) D. E. Fenton, Inorg. Chem. Commun. 2002, S, 537-547; c) R. Bosnich, Inorg. Chem. 1999, 38, 2554-2562; d) C. J. Qin, A. Gavrilova, B. Bosnich, Pure Appl. Chem. 2001, 73, 221-226; e) C. Belle, J.-L. Pierre, Eur. J. Inorg. Chem. 2003, 4137-4146.

[5] a) M. Konrad, F. Meyer, K. Heinze, L. Zsolnai, J. Chem. Soc. Dalton Trans. 1998, 199-205; b) M. Konrad, S. Wuthe, F. Meyer, E. Kaifer, Eur. J. Inorg. Chem. 2001, 2233-2240.

[6] a) J. C. Röder, F. Meyer, E. Kaifer, J. Organomet. Chem. 2002, 641, 113-120; b) T. Sheng, S. Dechert, A. C. Stückl, F. Meyer, Eur. J. Inorg. Chem. 2005, 1293-1302.

[7] T. Sheng, S. Dechert, I. Hyla-Kryspin, R. F. Winter, F. Meyer, Inorg. Chem. 2005, 44, 3863-3874.

[8] H. Zhang, S. Dechert, J. Maurer, M. Linseis, R. F. Winter, F. Meyer, J. Organomet. Chem. 2007, 692, 2956-2964.

[9] A. G. Blackman, Polyhedron 2005, 24, 1-39.

[10] a) J. C. Röder, F. Meyer, E. Kaifer, Angew. Chem. 2002, 114, 2414-2417; Angew. Chem. Int. Ed. 2002, 41, 2304-2306; b) J. C. Röder, F. Meyer, I. Hyla-Kryspin, R. F. Winter, E. Kaifer, Chem. Eur. J. 2003, 9, 2636-2648.

[11] K. G. Caulton, Coord. Chem. Rev. 1981, 38, 1-43.

[12] W. Kaim, R. Gross, Comments Inorg. Chem. 1988, 7, 269-285.

[13] F. Meyer, H. Kozlowski, in Comprehensive Coordination Chemistry II (Eds.: J. A. McCleverty, T. J. Meyer), Elsevier, Oxford, UK, 2004, vol. 6, pp. 247-554.

[14] T. Nagataki, Y. Tachi, S. Itoh, Chem. Commun. 2006, 40164018.

[15] a) G. B. Deacon, R. J. Phillips, Coord. Chem. Rev. 1980, 33, 227-250; b) V. Robert, G. Lemercier, J. Am. Chem. Soc. 2006, $128,1183-1187$.

[16] Values vs. the ferrocene/ferrocenium couple. $\Delta E_{\mathrm{p}}=E_{\mathrm{p}}{ }^{\mathrm{ox}}-E_{\mathrm{p}}{ }^{\mathrm{red}}$ $=64$ (for 3), 88 (for 4), or $65 \mathrm{mV}$ (for 5) with $\Delta E_{\mathrm{p}}\left(\mathrm{Cp}_{2} \mathrm{Fe} /\right.$ $\mathrm{Cp}_{2} \mathrm{Fe}^{+}$) $=60$ (for 3), 69 (for 4), or $80 \mathrm{mV}$ (for 5) under the same experimental conditions.

[17] R. Gross, W. Kaim, Angew. Chem. 1985, 97, 869-870; Angew. Chem. Int. Ed. Engl. 1985, 24, 856-858; P. M. Zizelman, C. Amatore, K. Kochi, J. Am. Chem. Soc. 1984, 106, 3771-3784.

[18] a) J. P. Bullock, K. R. Mann, Inorg. Chem. 1989, 28, 4006 4011 ; b) D. T. Pierce, W. E. Geiger, Inorg. Chem. 1994, 33, 373381.

[19] N. G. Connelly, W. E. Geiger, Chem. Rev. 1996, 96, 877-910.

[20] M. Kreijcik, M. Daniek, F. Hartl, J. Electroanal. Chem. 1991, 317, 179-187.

[21] G. M. Sheldrick, SHELXL-97, Program for Crystal Structure Refinement, University of Göttingen, Germany, 1997; G. M. Sheldrick, SHELXS-97, Program for Crystal Structure Solution, University of Göttingen, Germany, 1997.

[22] $X-R E D$, STOE \& CIE GmbH, Darmstadt, 2002.

[23] A. L. Spek, PLATON, A Multipurpose Crystallographic Tool, Utrecht University, 2003. 